\title{
THE EARNING OF FREIGHT ON UNCOMPLETED VOYAGES
}

\author{
EDWIN M. BORCHARD \\ Professor of Law, Yale University, School of Law
}

An inevitable consequence of the Great War was the interruption or breaking up of commercial voyages it necessarily brought about.

These acts of interference have occasioned much litigation on the question of the amount of freight earned by vessels thus rendered unable to complete their voyages, and have given renewed importance to an interesting subject of admiralty and contract law. The imagination has not conjured more varied and romantic circumstances than the actual facts of maritime adventure, as disclosed in the prosaic pages of the law reports. It may, therefore, be of interest to discover how the courts have dealt with the effect of these varying facts of force majeure, whether by act of man, God, or Government, in determining the validity and extent of the shipowner's claim to freight.

The contract of affreightment is practically always reduced to writing, whether in charter-party or bill of lading, and embodies the terms of the carriage. Leaving out of account the special contracts of time-charter and lump freight, ${ }^{1}$ the contract usually provides that freight shall be paid on a given quantity of cargo from port $A$ to port $B$ at a certain rate. This is the common use of the word "freight," and Scrutton defines it as "the reward payable to the carrier for the carriage and arrival of the goods in a merchantable condition, ready to be delivered to the merchant." 2 While primarily the right to and amount of freight depend upon the strict construction of the contract, the common form of contract and custom in the absence of special contract have led to the standard rule that freight is not earned until the cargo is delivered.

\footnotetext{
${ }^{2}$ Lump freight, according to Scrutton, The Contract of Affreightment (8th ed., I9I7) 327 , is a gross sum stipulated to be paid for the use of the entire ship; it is payable if the shipowner is ready to perform his contract, though no goods are shipped, or though part of the goods shipped is not delivered. But if shipped, some must be delivered to entitle the shipowner to lump freight. See The Norway (1865) 3 Moore P. C. (N. s.) 245; Thomas v. Harrouring S. S. Co. [rgr5, H. L.] A. C. 58 .

'Scrutton, op. cit., at p. 318, citing Kircher v. Venus (1859) I2 Moore P. C. 361, 390; Dakin v. Oxley (1864, C. P.) I5 C. B. (N. S.) 646, 665; Cargo ex Galam ( 1863, P. C.) B. \& L. I67.

Cook v. Jennings (1797, K. B.) 7 T. R. $38 \mathrm{x}$; Osgood v. Groning (1810, K. B.) 2 Camp. 466 ; Barker v. Cheriot ( 1807 , N. Y. Sup. Ct.) 2 Johns. 352 . In the latter case, Thompson, J., expressed the usual rule: "This was one entire voyage from New York to Martinique and back again; and as the vessel was
} 
In the courts of common law, the contract was deemed entire and indivisible, and the right to any freight depended upon full performance of the contract. This rule was not varied by the fact that part performance often conferred great benefit on the shipper, possibly even greater benefits than full performance would have. ${ }^{4}$ The courts of admiralty, however, frequently assumed jurisdiction of freight cases, particularly when the voyage had been interrupted by peril of the sea, and when, in time of war, their prize jurisdiction attached. These courts, being less strictly bound by technical rules of the common law, were more willing to allow equitable considerations to dictate greater liberality to the shipowner who, without fault on his part, had been prevented from completing the voyage, yet had performed much labor and had probably conferred benefit on the shipper. The influence of these courts induced a modification in all courts of the strict formula, by ascribing to certain operative facts legal effects which changed the position of the parties, either by excusing full performance without penalty of loss of freight, or by inferring a new contract for partial freight. To assume, therefore, that whenever a voyage is not completed no freight has been earned would be to court error. Probably the best method of arriving at the present state of the learning on the subject is to study the cases and operative facts which have raised the issue of freight. This we shall endeavor to do.

.PREPAID FREIGHT

The case of prepaid freight, at least according to English law, is somewhat beside our inquiry, for by the anomalous rule of that law, prepaid freight cannot be recovered, even in the event of the loss of the goods or non-completion of the voyage. ${ }^{5}$ While the rule of the

captured on her return, and did not deliver her return cargo, no freight is due, notwithstanding the defendant may have had the benefit of the outward voyage, because, by the express agreement of the parties, the outward and homeward voyages were one, and the profit depended upon the entire performance. This is too well settled to admit of being questioned."

Where capture, wreck, stranding, or theft by pirates prevents the cargo from reaching its destination, no freight is due according to continental law. Belgium, Commercial Code, Art. 97; France, Art. 302; Germany, Art 6r8; Holland, Art. 482; Italy, Art. 577; Spain, Art. 66r.

'Hopper v. Burness (1876) Q. B. 34 L. T. (N. s.) 528; The Industrie [1894, C. A.] P. 58, where sale of the cargo at an intermediate gort for legitimate maritime purposes brought a higher price than it would have at destination.

${ }^{s}$ Byrne v. Schiller (I87I) L. R. 6 Exch. 319, L. J. 40 C. L. (N. S.) 177; Allison v. Bristol Marine Ins. Co. (1876, H. L.) I A. C. 209, 226. Brett, J., in the latter case explains the rule thus: "It arose in the case of the long Indian voyages. The length of voyage would keep the shipowner for too long a time out of money; and freight is much more difficult to pledge, as a security to third persons, than goods represented by bill of lading. Therefore the shipper agreed to make the advance on what he would ultimately have to pay, and, for a 
American law ${ }^{6}$ and of the maritime countries of continental Europe makes no exception as to prepaid freight, commercial usage has usually attached to the prepayment of freight a bill of lading clause reading "Freight prepaid, and not to be returned, ship lost or not lost." This exceptional condition, having thus become a matter of contract, takes the case outside the customary rule as to the earning of freight.

\section{GENERAL RULE}

The true test of the right to freight, said Willes, J., in Dakin v. Oxley" is, "whether the service in respect of which the freight was contracted to be paid has been substantially performed," or, as laid down in other cases, ${ }^{9}$ whether its performance has been prevented by act of the shipper.

The courts have not been disposed to treat the contract of affreightment as dissolved by a capture or by a marine disaster..$^{0}$ Only when the circumstances indicate legal impossibility of performance or an abandonment of the transportation by shipowner or cargo-owner will the courts treat the original contract as terminated, or accord the shipper the privilege of so considering it.

consideration, took the risk in order to obviate a repayment, which disarranges business transactions." Cockburn, J., in Byrne v. Schiller, supra, said: "I regret that such should be the law. It seems to me to be founded upon an erroneous principle, and to be anything but satisfactory." See a learned note in (I87I) I5 Solicitor's Journal, 834 The rule began with Anonymous, Case 271 (1683, K. B.) 2 Shower, 283. See Coker v. Limerick S. S. Co. (I918, H. L.) 34 Times L. R. 296. Parties may of course contract that freight shall be paid on consideration of the cargo being taken on board, or the voyage merely begun.

'Griggs v. Austin (1825, Mass.) 3 Pick. 20; Minturn v. Warren Ins. Co. (I861, Mass.) 2 Allen, 86; Watson v. Duykinck (1808, N. Y. Sup. Ct.) 3 Johns. 335.

${ }^{7}$ The Gracie D. Chambers. (1918, C. C. A. 2d) 253 Fed. 182, (1919) 28 Yale Law Journal, 279, (r919) 248 U. S. 387, 39 Sup. Ot. I49; Allanwilde Transport Co. v. Vacuum Oil Co. (1918) 248 U. S. 377,39 Sup. Ct. 147.

${ }^{8}$ Supra note 2 , at p. 664 .

- Cargo ex Galam, supra note 2; Cargo ex Argos (1873, P. C.) L. R. 5 A. C. 134 .

${ }^{10}$ The Racehorse (1800, Adm.) 3 C. Rob. 10I ; Palmer v. Lorillard (1809, N. Y.) I6 Johns. 348, 354; The Nathaniel Hooper (1839, C. C. Ist) 3 Sumner, 542; The Teutonia (1872, P. C.) 4 A. C. I7I, 182, I Aspin. 214, 220. In the last case it was said: "The contract is not to be treated as dissolved if by any reasonable construction it can be treated as still capable in substance of being performed." Ozens v. Breitung (IgIg, U. S. D. C., S. D. N. Y.) N. Y. LAw Journat, Aug. I2, IgI9, aff'd. Dec. 8, I920, C. C. A. 2d. According to continental maritime law generally, the shipper must wait a reasonable time until the impediment to continuance of the voyage is removed; the law usually enumerates the cases ( $I$ ) in which one party or the other is justified in treating the contract as cancelled, and (2) in which the law automatically dissolves the contract. Sieveking, German Law relating to the Carriage of Goods by Sea, (London, 1907) $78,228$. 
The law affords the shipowner, where his ship has met with an impediment, a reasonable time still to earn his freight, either by repairing or transshipping in another vessel. ${ }^{x 1}$ Only after he has had such an opportunity and has failed to avail himself thereof is the contract deemed abandoned, and the owner of the goods entitled to have them, without payment of any freight. In the case of Clark $v$. Massachusetts Fire and Marine Ins. Co., ${ }^{12}$ two months was considered not an unreasonable time for this purpose.

One of the clearest legal expositions of the effect of an extraneous impediment or interference on the contract of affreightment after the voyage has been begun, is to be found in a decision of Chief Justice Kent in the case of Palmer $v$. Lorillard..$^{33}$ In that case a cargo of tobacco from Richmond to New York was, after reaching Norfolk, prevented from going forward by a British blockade at Hampton Roads. The shipper, demanding his goods, contended that the contract of affreightment was dissolved and that he was entitled to his goods without payment of freight. Kent answered the contention as follows:

"It is a general, and an acknowledged rule, that the voyage must be performed according to the contract, before the shipowner or master can demand his freight. The conveyance and delivery of the cargo is a condition precedent, and must be fulfilled. A partial performance is not sufficient; nor can a partial payment be clained, except in special cases. But if the delivery be prevented by the act of the shipper, or if he dispense with it, the master may then demand his whole freight. ...

"It is only contended by the defendants below that the contract was still in operation, and that they had a right to retain the goods, and wait for an opportunity to fulfil the contract; and that if the other party elected to receive back their goods, they were then bound to pay the freight. The reason is, that the blockade of the mouth of the Chesapeake by British ships did not dissolve the contract, but only suspended for the time its performance, and the defendants had a continuing and subsisting right to wait until they had an opportunity to go to sea. This was a right they had, and it was the only means of indemnity for the time, labor and expense already bestowed upon the contract. The plaintiffs could not deprive them of this right without their consent, or without tendering to them the stipulated compensation. . . .

${ }^{11}$ Cook v. Jennings, supra note 3 ; Shipton v. Thornton (1838, Q. B.) 9 Ad. \& El. 314, 335; The Maggie Flanmond (1869, U. S.) 9 Wall. 435, 458; Harrison v. Fortlage (I896) I6I U. S. 57, 64, I6 Sup. Ct. 488; The Blenheim (I885, Adm.) 10 $P$. 167. The continental codes generally expressly provide that the shipper must wait a reasonable time for the repair of the ship. Belgium, Com. C. Arts. 89, 94; France, Art. 296; Germany, Arts. 638, 640; Holland, Art. 478; Italy, Art. 57.0; Spain, Arts. 677, 683.

12 (1824, Mass.) 2 Pick. I04. Several continental codes specify in certain contingencies, such as embargo or outbreak of war, the time the shipper must wait, usually three, sometimes five months.

${ }^{13}$ Supra note 10, at p. 354 . See also Story, J. in Jordan v. Warren Ins. Co. (I840, C. C. Ist.) I Story, 353 ; The Teutonia, supra note ro. 
"The case of an embargo is a very strong case in the English law to show that a temporary impediment to a voyage does not, of itself, work a dissolution of the contract of affreightment; and as long as the contract remains in force, it will undoubtedly be conceded, that neither party can, by his own act or volition, dissolve it without the assent of the other. It is well settled that an embargo does not dissolve any maritime contract. It is only a temporary restraint which suspends for a time its performance and leaves the rights of the parties in relation to each other untouched."

The legal relations between the parties with respect to freight when the voyage has been interrupted by unavoidable cause have been succinctly described by Lord Ellenborough in the leading case of Hunter v. Prinsep. We quote from the opinion of Mr. Justice Blatchford in The Tornado. ${ }^{14}$

"The law in regard to the respective rights and liabilities of shipper and shipowner, where cargo has been carried for a part of a voyage, is nowhere better expressed than by Lord Ellenborough, in Hunter $v$. Prinsep, Io East, 378, 394:

"The shipowners undertake that they will carry the goods to the place of destination, unless prevented by the dangers of the seas, or other unavoidable casualties; and the freighter undertakes that if the goods be delivered at the place of their destination he will pay the stipulated freight; but it was only in that event, viz., of their delivery at the place of destination, that he, the freighter, engages to pay anything. If the ship be disabled from completing her voyage, the shipowner may still entitle himself to the whole freight, by forwarding the goods by some other means to the place of destination; but he has no right to any freight if they be not so forwarded; unless the forwarding them be dispensed with, or unless there be some new bargain upon this subject. If the shipowner will not forward them, the freighter is entitled to them without paying anything. One party, therefore, if he forward them, or be prevented or discharged from so doing, is entitled to his whole freight; and the other, if there be a refusal to forward them, is entitled to have them without paying any freight at
all."

There are then several possibilities when a voyage is interrupted by extraneous agency: the shipowner may be entitled to no freight, to partial freight, or to full freight, depending upon the circumstances.

To determine the present state of the law it has seemed best to make an analysis of the cases that have arisen, and to classify them according to their operative facts. Only thus will it be apparent that a fairly clear line runs through them, and only thus will a systematic presentation of legal doctrine be possible.

\section{NO FREIGHT}

The cases in which no freight has been allowed on uncompleted voyages, in application of the general rule, disclose the presence of

x4 (1882) I08 U. S. 342, 347, 2 Sup. Ct. 746, 749. 
operative facts making the legal conclusion either equitable or necessary by reason of a contract stipulation: The classification essayed below indicates therefore a limited application of the rule to specific types of cases; where these operative facts are not present or where other facts are present, to be detailed hereafter, either pro rata freight or full freight has been allowed the shipowner.

(a) No freight has been allowed where there was a total defeat of the object of the voyage.

Ships have occasionally started on their voyages, but before proceeding any substantial distance they were brought back, owing to some supervening cause, either war or marine disaster. In such cases, it has been held that there was a total defeat of the object of the voyage and no freight has been allowed. ${ }^{15}$

In the recent case of The Appam, ${ }^{16}$ a vessel on a voyage from

${ }^{25}$ The Isabella Jacobson (18or, Adm.) 4 C. Rob. 77 (Ship few days out on a long voyage, met bad weather, became leaky and returned. Swedish embargo then prevented sailing and cargo unladen and restored to shippers). Almost identical facts in Allanwilde Transport Co. v. Vacuum Oil Co., supra note 7 led to a different conclusion, because freight was prepaid and by bill of lading was to be retained "irrevocably." Liddard v. Lopes (I809, K. B.) ro East, 525; Birley v. Gladstone (I814, K. B.) 3 M. \& S. 205; Curling v. Long (I797, C. P.) I B. \& P. 634 (Ship captured in the river before "breaking ground," recaptured, taken to another port and cargo sold for benefit of shippers; no freight allowed because the ship had not "conferred any benefit on the freighters by the carriage, or bettered the goods in the smallest degree by the expenses incurred."); The Louisa (1813, Adm.) I Dod. 317, 319 ("the voyage having been totally defeated by the sale of the goods at Corunna," an intermediate port of distress, without consent of the owners, under authority of the British Vice-Consul).

The continental law is based on different principles, looking not to the benefit conferred but to the burden and labor borne by the ship. Thus in case delivery becomes impossible after commencement of the voyage by reason of a prohibition of trade with the port of destination, the following rules prevail: If the ship is chartered "out and home," freight is due for the outward voyage, according to the law of Belgium (Com. C. Art. 9I), France (Art. 299), Holland (Art. 504). In Italy (Art. 572) full freight is due even if the captain must put back to the port of origin, but if the ship is chartered "out and home," one-half the entire freight or of the two freights together is due. In Portugal Art. $54^{8}$ accords pro rata freight if delivery is prevented by vis major, war, blockade or prohibition of trade, and by Art. 549 outward freight plus one-third freight for the return or extra voyage is due, whether the ship comes back or goes to another port. In Germany, the rule is complicated by the question whether the prohibition is due to ship or cargo, and whether the voyage is thereby completely terminated or only delayed. The general rule is that if either party would by the facts be privileged to cancel the contract, pro rata freight according to distance covered has been earned. Cf. Art. 630,634 . Sieveking, $o p$. cit. note Io, at p. 228, ff. Where, however, the cargo is completely lost short of its destination by wreck, stranding, theft by pirates, or capture by enemies, no freight is due according to continental law. Belgium (Com. C., Art. 97), France (Art. 302), Germany (Art. 6r8), Holland (Art. 482), Italy (Art. 577), Spain (Art. 66I).

${ }^{10}$ (19I7, S. D. N. Y.) 243 Fed. 230, 234. In the leading case of Luke v. Lyde 
Africa to England was captured by a German raider, a prize crew was put on board, and she was brought by that crew to Norfolk, Va. The owner's claim for a possessory lien for freight was disallowed because of the total defeat of the object of the voyage, in addition to the loss of the lien by the hostile capture and abandonment of the original voyage.

(b) No freight has been held due where the completion of the voyage was rendered illegal.

In several cases arising at the beginning of the European War, a British ship bound for a German port was barred from continuing the voyage to Germany on the ground that the war had made such a voyage illegal for a British ship. The leading case probably is that of The St. Helena, ${ }^{17}$ bound with a general cargo including phosphate rock from Tampa, Florida, to Hamburg. Reaching the Lizard on August 3 , I9x4, she was warned by the Admiralty of the imminence of war and of the advisability of taking the goods to an English port. This was done. On August 4, war was declared between England and Germany and the further prosecution of the voyage became illegal and impossible. The phosphate was released to the defendants as neutral owners, whereupon the plaintiff shipowners asked in the King's Bench Division for a declaration that they were entitled either to full or pro rata freight. Rowlatt, J., dismissed the action on the ground that, the voyage not having been completed, no freight was due, and that by taking the goods from the court in England no new agreement could be inferred to substitute the new voyage for the original one and hence pro rata freight was not due. The case was distinguished from The Teutonia, ${ }^{18}$ in which a voyage to Dunkirk, France, by a German ship was likewise rendered illegal by the outbreak of the Franco-Prussian war of I870. The ship put into Dover, England, where the consignee accepted the goods. The same full freight as to Dunkirk was allowed, because under the contract Dover was construed to be an alternative port of delivery.

(I759, K. B.) 2 Burr. 882, there was a similar deviation by capture and recapture, after 17/2I parts of the voyage from Newfoundland to Lisbon had been completed. The ship was taken to Biddleford, a greater distance from Lisbon than Newfoundland. Lord Mansfield nevertheless allowed pro rata freight, presumably on the theory of detriment to the plaintiff, and apparently because the shipper took the goods at Biddleford. The decision has been severely criticized, as contrary to principle, which requires "benefit to the defendant" See Keener, Quasi-Contracts (1893) 253. Mansfield attributed great weight to the acceptance by the shipper, without inquiring closely whether it was voluntary or involuntary, an important criterion in the later cases.

${ }^{17}$ The suit of the shipowners against the cargo-owner was first brought in the King's Bench Division as St. Enoch Shipping Co. v. Phosphate Mining Co. (an American corporation) [1916] 2 K. B. 624; the owners later made their demand for freight in the Prize Court, where on appeal to the Privy Council it was likewise disallowed. The St. Helena [1916, P. C.] 2 A. C. 625.

${ }^{28}$ (187x, Adm.) 3 A. \& E. 394, (1872, P. C.) L. R. 4 A. C. I7I. See note Io, supra. 
The owners of the St. Helena then made their demand for freight in the Prize Court, which has jurisdiction of all incidents of a prize seizure, even where goods are ultimately released.19 Although Sir Samuel Evans allowed some freight, referring the amount to a referee, the Privy Council on appeal disallowed the claim on the ground that the contract of affreightment was terminated when, on August 7 , the shipowners abandoned the voyage which had become illegal on August 4 by the outbreak of war. That abandonment ended all claim to freight; and it could not be revived by a subsequent seizure of the goods by a Prize Court.

It will be observed hereafter that prize courts have frequently awarded compensation in lieu of freight to shipowners against captors where, by reason of a seizure jure belli, which turns out to be unlawful, the ship has been deprived of the opportunity of earning freight which, but for the seizure, it lawfully could have earned. So where the seizure results from the incapacity of the goods, rather than of the ship. Even where the incapacity attaches to both, compensation has been allowed in the discretion of the Prize Court, particularly where the voyage when begun was lawful. ${ }^{20}$ Even as between shipowners and cargo-owners such a claim has been allowed. ${ }^{21}$

(c) No freight is due where suit therefor is brought on the original contract, but there has been a failure of full performance.

When suit for freight on an uncompleted voyage has been brought in covenant, nothing less than full performance has been deemed to warrant recovery. In these cases, though force majeure prevented delivery, it has been held that the shipowner assumed the risk of inability to deliver as covenanted. To sustain a claim to freight, some new operative fact must have intervened, such as a waiver of delivery by the shipper by word or act, and the suit must then be in assumpsit on a new implied contract.

This rule has been applied in several extreme cases. For example, in Scott $v$. Libby, ${ }^{22}$ a vessel was chartered on a voyage from New York

\footnotetext{
${ }^{20}$ The Corsican Prince [1916] P. 195; The Appam, supra note 16.

${ }^{20}$ The Juno [1916] P. I69.

${ }^{2}$ So with respect to cargo released to Russian owners, without admission of wrongful seizure, from a British ship sailing from a Black Sea port to Hamburg, before the outbreak of war, the ship putting into England after the declaration of war, where cargo was seized as prize. The Iolo [1916] P. 206, 212. The rule of continental law where war makes continuation of voyage illegal is stated in note 15 , supra.

22 (1807, N. Y. Sup. Ct.) 2 Johns. 336. See also The Hiram (1800, Adm.) 3 C. Rob. I80. Luke v. Lyde, stupra note 16, was distinguished by Sir William Scott because the cargo there had been carried to Biddleford, and not back to the port of departure, though it is hard to see how any more benefit was conferred on the cargo-owner by taking it to Biddleford, further from its destination, Lisbon, than Newfoundland, the port of origin. Luke v. Lyde, though used as an authority, lacks every foundation of reason for sustaining pro rata freight, except possibly voluntary acceptance by the shipper, which is by no means clear.
} 
to St. Domingo and return. On arriving in sight of St. Domingo she was turned away by a British cruiser, the port being blockaded, and returned with her cargo to New York. In an action of trover, for goods detained for freight, it was held that delivery of the cargo was a condition precedent to freight, and the blockade having under the circumstances dissolved the charter party, and no new implied contract being inferrable from waiver of delivery or acceptance at any intermediate port, the claim to freight either under or outside the contract must fail. Of course, no benefit was conferred on the cargo when it was brought back to New York. ${ }^{23}$

In Cook v. Jennings $s^{24}$ the action was in covenant for freight on a cargo of deals to be delivered at Liverpool from Wiborg. The ship was wrecked and the deals put ashore in Denmark, where the cargoowner had to take them against his will to preserve his property. Suit on the covenant was held to require delivery at Liverpool, and barred any claim for less than full freight, in the absence of an express new agreement. The rule was not varied even where the sale of part of the cargo for necessary repairs at an intermediate port of distress was effected at a much higher price than the price of destination $;^{25}$ nor

${ }^{3}$ The French Ordonnance de la Marine (I68I) (Valin, Commentaire, Book 3, Tit. 3, Art. 15) gives the shipowner outward freight, when commerce with the port of destination is prohibited after departure of the vessel. The same rule is embodied in Art. 299 of the French Commercial Code. For the rules of continental law, see note 15 , supra.

${ }^{24}$ Supra note 3. So in Osgood $v$. Groning, supra note 3 , where on a voyage under charter from Charleston to Hamburg, plaintiff's vessel was advised in the English Channel that the Berlin and Milan decrees would subject the vessel to confiscation if it proceeded to the continent. It therefore put into London, and discharged. The cargo-owners refused to receive the cargo short of destination. It was held that the shipowners were entitled neither to freight under the contract, not having performed, nor to compensation for the voyage as far as London, there being no substituted agreement, express or implied, for partial freight. See also The Industrie, supra note 4, at p. 75 (sale of damaged cargo by master in port of distress; by German law full freight is allowed under such circumstances, the master being considered the agent by necessity of the cargo-owner). In Castel and Latta v. Trechman (1884, Q. B.) I Cab. \& El. 276, the port of destination, Taganrog, was under blockade, and so the ship made delivery at Constantinople. Although this was a reasonable course to pursue, it was held not covered by the clause "so near thereunto as she could safely get," and there being no voluntary acceptance or new agreement by the shipper, no freight was allowed.

${ }^{25}$ Hopper v. Burmess ( 1876, Q. B.) 34 L. T. (N. S.) 528 (the shippers being given the option to demand damages for the sale or to treat the proceeds as a forced loan; having done the latter, they were not liable for any freight). The continental rule of maritime law would be different; full freight would be allowed in Belgium (Com. C., Art. 93), France (Art. 298), Holland (Art. 480), Germany (Art. 617, Sieveking, op. cit. note 10, at p. 227), Italy (Art. 575), Portugal (Art. 555), and Spain (Art. 659), the captain being deemed the agent of the shipper, where sale is for legitimate maritime needs. Accounting for the price in general average is implied. But where, after sale at the intermediate port, the ship is lost, pro rata freight only is due. Germany (Art. 632), Holland (Art. 48a), Spain (Art. 659-2). 
where the ship meeting with disaster, was abandoned by her crew and brought to her destination by salvors, the cargo being there sold and half the proceeds turned over to the shippers. No freight was in this case allowed in a suit on the charter-party, though a quaere was raised, whether an action in assumpsit might not have justified pro rata freight. ${ }^{26}$

(d) No freight has been allowed where the shipper has been compelled, werithout prior intention or premeditation, to receive his cargo: (or the proceeds thereof) either from a prize court or court of admiralty or at an intermediate port after shipwreck or other disaster.

In the leading case of Hunter $v$. Prinse $p^{27}$ a cargo was sold at an intermediate port by the master without authority of law, after a wreck, and the shipowners claimed the proceeds on account of freight pro rata itineris. The claim was denied, principally because the shipper had not assented to the sale; by mere acceptance of the proceeds, it was held, he had not indicated an intention to dispense with the delivery of the cargo at its destination. By the sale the master had placed such delivery beyond his power. The effort was made to distinguish the case of Baillie $v$. Moudigliani, ${ }^{28}$ in which freight pro rata was allowed the shipowner out of the proceeds of a sale by an admiralty court, on the theory that in that case the sale was lawful. Subsequent cases, however, have established the conclusion that the justifiability of the sale makes no difference whatever. ${ }^{29}$ Any sale without the shipper's consent bars freight. For even where the shipper has had to take his goods from the hands of the court, the shipowner being unable or unwilling to forward them, no freight has been allowed. ${ }^{30}$ So where

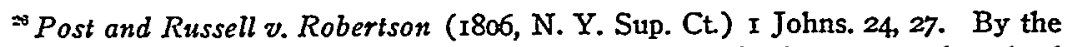
law of several continental countries, pro rata freight is due on goods salved after shipwreck or recapture. France (Art. 303), Germany (Art. 632), Holland (Art. 483), Italy (Art. 578), Spain (Art. 662).

${ }^{27}$ (1808, K. B.) ro East, 378.

${ }^{28}$ (1785, K. B.) Park, Marine Insurances (6th ed. 1809) 70. Lord Ellenborough in Hunter v. Prinsep also pointed out the very special facts of the Baillie Case, which he deemed unique and alone sustained the judgment.

${ }^{20}$ Vlierboom v. Chapman (1844, Exch.) I3 M. \& W. 230, 238; Hopper v. Burness, supra note 25. Had the shipowner insured the freight, he might, of course, recover it on a policy of insurance, though he could not recover it from the shipper. The rule in the maritime law of continental Europe is different; a justifiable sale for maritime necessity entitles the shipowner to full freight (supra note 25). Even in the case of goods jettisoned for the common benefit, full freight is due, subject to general average adjustment. Belgium (Art. 96), France (Art. 30I), Germany (Arts. 619, 713), Holland (Art. 48I), Italy (Art. 576), Portugal (Art. 555). In Spain (Art. 660) pro rata freight is allowed, subject to general average.

${ }^{30}$ The Fortuna (1809, Adm.) Edw. 56, 58; Sampayo v. Salter (1816, C. C. D. N. H.) I Mason, 43; Caze v. Baltimore Ins. Co. (1813, U. S.) 7 Cranch, 358; Hurtin v. Union Ins. Co. (1806, U. S. C. C. 3d) I Wash. 530; Armroyd $u$ Union Ins. Co. (I8II, Pa.) 3 Binn. 437. On the continent, pro rata freight would in such cases generally be due, assuming the ship put in in distress and was unable to proceed. See France (Art. 296), Holland (Art. 478), Italy (Art. 570), Spain (Art. 657). 
goods are taken over by the owner at an intermediate port after shipwreck or other maritime disaster or impediment preventing delivery at destination. ${ }^{31}$ The essential element of the disallowance of freight in these cases is that the shipper, making the best of a bad or unexpected situation, has been compelled against his will and without an option in the matter, to receive his cargo at an intermediate port.

(e) Where there has been an abandonment of the vessel and the voyage by the master or shipozener, no freight has been allowed, even though salvors ultimately brought the cargo to port.

It was not an easy problem to determine the effect upon a contract of affreightment of a compulsory abandonment of a vessel through peril of the sea. On the one hand, it was argued that property in the vessel is not lost by this act, any more than it is by belligerent capture, and that therefore no intention to abandon the contract can be assumed. If the cargo therefore is brought to port by salvors, the shipowner should have the opportunity of earning his freight by resuming the voyage, or, if the cargo-owner claims his goods, he should pay the shipowner reasonable compensation for his services. ${ }^{31 a}$

On the other hand it was argued that the abandonment of the vessel without intention to retake possession, if not a repudiation of the contract, was at least such a departure from its terms and intent, that it gave the cargo-owner the privilege of electing to treat the contract as terminated and of taking his cargo wherever he could get it, without payment of any freight. This is the argument that has prevailed in the courts. ${ }^{32}$ It was sustained by Justice Holmes in a five to four decision in the case of The Eliza Lines, ${ }^{33}$ where a vessel on her way from Pensacola to Montevideo was justifiably abandoned by her crew in consequence of a sea peril and brought to Boston by salvors. The

"Osgood v. Groning, supra note 3; Cook v. Jennings, supra note 3; Metcalfe v. Brittania Iron Works Co. (I877, C. A.) L. R. 2 Q. B. 423,36 L. T. 451 (original destination being blocked by ice, cargo landed at another port against owner's protest); Castel and Latta v. Trechman, supra note 24; Hill v. Wilson (1879) L. R. 4 C. P. 329 (damaged cargo sold, without shipper having opportunity to exercise any option). On the continent, pro rata freight would in such cases generally be due, assuming the ship put in in distress and was unable to proceed. See France (Art. 296), Holland (Art. 478), Italy (Art. 570), Spain (Art. 657). If the captain was able and willing to proceed after repair or to transship in another vessel, the shipper could have his goods only on payment of full freight.

${ }^{21} \mathrm{a}$ This in fact is the general rule of continental law. Supra, note 26.

"The Kathleen (1874, Adm.) L. R. 4 A. \& E. 269, 2 Aspin. 367; The Cito (I88I, C. A.) 7 P. 5, 4 Aspin. 468. See the severe criticism of the Cito Case by Wendt, Papers on Maritime Legislation (3d ed. I888) 627 and the distinction he makes between The Kathleen; where the cargo was too badly damaged to warrant carriage to destination, and $T h e$ Cito, where the cargo was practically undamaged. The Arno (1895, C. A.) 72 L. T. 621, 8 Aspin. 5; The Eliza Lines (1905) 199 U. S. 119, 127, 26 Sup. Ct. 8, 9.

Supra note 32 . 
master claimed the vessel and asserted his intention of proceeding with the voyage; to this the cargo-owners objected, claiming the cargo without duty to pay freight. This contention the court sustained, dismissing as immaterial the point, left open in The Cito and The $A m{ }^{34}$ whether the shipowner, regaining possession of the vessel before the cargo-owners had intimated an election, might keep the contract alive for the purpose of enabling him to carry on the goods and earn his freight. It seems that only the cargo-owner has the election of treating the contract as subsisting or terminated, and it would seem that it is immaterial whether the abandonment was justifiable or not. In case of unjustifiable abandonment, the shipper would still have his action for tort, without liability for freight.

But the important operative fact is the abandonment without animus revertendi or spes recuperandi. Bruce, J., in The Arno said:

"The real question is whether, so far as the owner of the ship is concerned, there was on his part, or on the part of his servants, an act done so clearly indicating his intention not to carry out the contract, as to entitle the owners of the cargo to treat that act as putting an end to the contract."

Applying this test, the act of the crew of a ship in distress boarding a rescue ship, the two ships being navigated to an intermediate port in company, was construed as not an abandonment conferring a privilege of election to terminate the contract, so that the shippers could not obtain their cargo except on payment of freight. ${ }^{35}$ Nevertheless, it is not easy to support. the decision of the House of Lords in the recent case of Bradley v. Nezusom, Sons $\mathcal{E} \mathrm{Co}_{.}{ }^{36}$ in which the defendant's ship, while on a voyage from Archangel to Hull, with a cargo of lumber, was attacked by a German submarine off Scotland, and the crew compelled to leave the ship. The Germans attempted to blow up the ship, but her cargo kept her afloat, and she was subsequently towed into Leith by a patrol boat. The master, however, believed that she had been sunk and so telegraphed his owners. The cargo-owners, learning of her arrival at Leith, claimed possession, free from any claim to freight, on the ground that the defendants had abandoned the prosecution of the voyage. The defendants later carried the cargo to Hull, without prejudice to the rights of the parties. The majority of the Hoùse of Lords, reversing the Court of Appeal, held that as the

\footnotetext{
s4 Supra note 32.

${ }^{25}$ The Leptir (I885, Adm.) 5 Aspin. 41r. Pro rata freight was allowed. On principle; however, the shipowner's unwillingness or inability to go on not being shown, full freight should have been allowed, if the shippers insisted on taking their cargo. That would be the rule of continental law, where there was a possibility and willingness to forward the goods. Belgium (Arts. 89, 92, 94), France (Arts. 296, 299), Germany (Arts. 637, 638, 640), Holland (Arts. 478, 502), Italy (Arts. 570, 572), Portugal (Art. 549), Spain (Arts. 677, 683).

* [1919, H. L.] A. C. I6. Under principles of continental law, full freight would likewise have been held due.
} 
crew in leaving the ship yielded only to force, there was no abandonment without intention to return, but only a temporary interruption entitling the shipowner to proceed to earn his freight when he recovered his vessel. But they apparently left out of account the important evidential fact that the master thought the ship had sunk and so telegraphed his owners, thus indicating clearly that he had no intention of returning. Lord Sumner, in his dissent, alone stressed this fact, which to the writer seems decisive. Justifiable abandonment is always induced by supervening force majeure, and it would seem not to be material whether nature or the armed force of the enemy is the operative cause. ${ }^{37}$

(f) No freight has been held due when the cargo was disposed of (or there has been some default) by the master or shipowner at an intermediate port.

There have been many cases in which a cargo from a stranded or damaged ship has been sold in an intermediate port by the master. Often these sales are necessary, and are made in the best interests of all parties concerned. But whether justifiable-for example, to obtain funds for repairs or to save as much as possible out of a perishable or damaged cargo $^{38}$-or unjustifiable and unlawful, ${ }^{39}$ no freight is allowed the shipowner, unless there has been such authority from the shipper as to warrant the courts in implying a new agreement to pay freight. The theory supporting these decisions is that the master by his own act has placed it out of his power to carry on the cargo and earn his freight.

In Welch $v$. Hicks, ${ }^{40}$ the vessel having stranded on the voyage, the owner of the cargo negotiated for several days with the master in order to induce him either to repair his vessel and forward the goods or to hire another ship. The master refused to do either. It was held that the owner, under these circumstances, was entitled to take his goods without payment of freight. The wilful default in duty of the master forfeited his claim to freight.

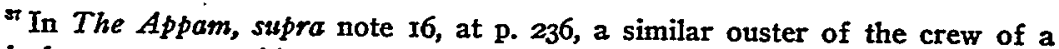
ship by an enemy raider and her carriage to a port thousands of miles out of her course was construed as an abandonment. Continental law would probably have allowed pro rata freight to the place of capture in this case, the goods not having been completely lost to the owner. France (Art. 303), Germany (Arts. 630, 632), Holland (Art. 483), Italy (Art. 578), Spain (Art. 662).

${ }^{28}$ Hopper v. Burness, supra note 25; Hill v. Wilson, supra note 3r; The Industrie, supro note 4

The continental rule is different. Full freight is due on goods thus sold, if the ship reaches her destination; pro rata freight, if she does not. Belgium (Art. 93), France (Art. 298), Germany (Arts. 632, 638, 640), Italy (Art. 575), Portugal (Art. 555), Spain (Art. 659).

${ }^{20}$ The Harriet (I848, E. D. Penn.) Fed. Cas. 6094; Sampayo v. Salter, supra note 30 ; Hunter v. Prinsep, supra note $27 ; V a n$ Omeron v. Dowick ( $1809, K$. B.)
2 Camp. 42 .

(1826, N. Y. Sup. Ct.) 6 Cow. 504. See also Portland Bank v. Stubbs (1810) 6 Mass. 422.
} 
In all these cases where no freight was held to have been earned, it will have become apparent that the failure to deliver the cargo at destination was due either to an unforeseen event beyond control of the parties, or to the act or omission of the shipowner or master. The cargo-owner's conduct was in no sense a contributing cause to the default. As will presently be observed, where the courts have been able to construe the act or omission of the cargo-owner as an operative fact contributing either directly or indirectly to the default or non-delivery, they have granted the shipowner some freight, either entire or in part, depending upon the circumstances.

\section{FULL FREIGHT}

It has already been ubserved that upon the happening of a maritime disaster interrupting the voyage at an intermediate port, the contract is not terminated, but the master has the privilege either of repairing his ship and carrying on or of transshipping the cargo in another vessel. There appears to be some difference among the early authorities on maritime law as to whether this was a duty of the master or merely a privilege. By the Rhodian law, the laws of Oleron, and the ordinances of Wisbuy it appears to have been a privilege; by the French Ordonnance de la Marine, it appears to have been a duty."1 At all events, in Anglo-American maritime law it appears to be the master's privilege, if he desires to earn his full freight. "Perils of the sea" being usually excepted in the bill of lading or charter-party, he will not be under a duty to go on, but he cannot of course demand any freight, unless the shipper prevents him from carrying out his intention to go on. It has also been noted that the master has a reasonable time to determine what he will do, and a reasonable time to carry out his decision. ${ }^{22}$

(a) Full freight is due where the shipper by act or omission prevents the shipozener or master from completing the voyage.

Numerous cases have arisen in which the cargo-owner has demanded his goods at an intermediate port, or has declined to permit the master to proceed with the voyage. This default or waiver by the shipper, the master being willing and able to go on within a reasonable time, is deemed to entitle the shipowner to his full freight. Should the master be unwilling or unable to forward the cargo, he will then be deemed to have terminated the contract and, as we have seen, the shipper may have his cargo without payment of freight. But to bring about this

\footnotetext{
a The controversy among the French authorities as to whether it was a privilege or duty is summarized by Lord Denman, with citation of authority, in Shipton v. Thornton ( 1838, Q. B.) I P. \& D. 216, 232. According to the law of Belgium (Art. 94), France (Art. 296), and Holland (Art. 478), the captain must hire another vessel to carry the goods forward. If he cannot do so, practically in all continental countries he is entitled to pro rata freight.

"By Lord Kingsdown in Cargo ex Galam, supra note 2, at p. 178; Clark v. Mass. Fire and Marine Ins. Co., supra note 12.
} 
result, there must be clear evidence of the master's inability or unwillingness, such, for example, as an overt act of abandonment. If the two parties agree, expressly or by implication, to waive further carriage and the shipper voluntarily accepts his cargo, pro rata freight, as will presently be shown, is due.

Judge Story in a well-reasoned opinion in the Circuit Court in Jordan v. Warren Ins. Co.43 gave what is believed to be a correct if not complete exposition of the law:

"It is as clear that after the shipment of the cargo on the voyage, the shippers have no right to demand it at any intermediate port, short of the port of destination, without payment of full freight for the voyage, whether the cargo arrive there in a damaged or in an undamaged state. The reason is obvious. The master has a right to carry on the cargo to the port of destination; and if his ship be capable, either then or within a reasonable time, to carry the cargo to the port of destination, there is no ground to say that he is not entitled to earn a full freight; and the shippers of the cargo cannot insist on changing the original contract in invitum, and cut him off from all freight or dismiss him with a pro rata freight. ...

"If [the shippers] did not choose to pay the freight, the master had. a right to retain the cargo for the payment thereof, or to prepare it again for reshipment, as soon as it could be safely done, unless the owners refused to allow it to be again reshipped on the voyage. If they did so refuse, then the contract for full freight would have been complete on the part of the shipowner, from the default on the other side." 44

A unique case illustrating the principle arose during the recent war. The German steamer Dacia, while in an American port in 19I4, having been purchased by an American citizen and transferred to the American

\footnotetext{
${ }^{43}$ Supra note 13, at p. 354. See also Story's statement in the earlier case of The Nathaniel Hooper, supra note 10: "And I think the whole of the cases, in which the full freight is upon the ordinary principles of commercial law due, notwithstanding the non-arrival of the goods at the port of destination, may be reduced to the single statement, that the non-arrival has been occasioned by no default or inability of the carrier ship, but has been occasioned by the default or waiver of the merchant-shipper. In the former case, the merchant-shipper cannot avail himself of his own default to escape from the payment of freight; in the latter case he dispenses with the entire fulfillment of the original contract for his own interest and purposes." A mere temporary interruption of the voyage by maritime disaster, not putting an end to the possibility of continued carriage, would not, of course, constitute a "default or inability of the carrier ship." So by continental law generally, if the shipper declines to wait until repairs are completed and demands his goods at the port of refuge, full freight is due; pro rata freight would be due if the shipper can prove that the shipowner was unable or unwilling after reasonable time to proceed or transship. Belgium (Arts. 89, 92), France (Arts. 296, 299), Germany (Arts. 637, 640), Holland (Arts. 478, 502), Italy (Arts. 570, 572), Portugal (Art. 549), Spain (Arts. 677, 684).

"The same point is illustrated by Palmer v. Lorillard, supra note ro; The Soblomsten (1866, Adm.) L. R. I A. \& E. 293, 298; Braithwaite v. Power (1891) I N. Dak. 455,48 N. W. 354 See also Schouler, Bailments (3d ed., I897) sec. 528; 2 Parsons, Contracts (9th ed., I904) 425.
} 
flag, was chartered to carry a cargo of cotton from Galveston to Rotterdam, the final destination of the cotton being Bremen. The shipowner was assured by the Solicitor of the State Department that the transfer of flag was legal. The British Government, however, while not having as yet declared cotton contraband, had no disposition to encourage the cotton trade of the South with Germany, and let it be known that they would probably take the ship into a prize court for adjudication; but they assured the shipper, in conference in Washington, that they would either forward the cotton or purchase it at the full Bremen contract price. The shipper thereupon made all his arrangements to sell the cotton to the British Government. This he preferred to forwarding, as he thereby saved freight charges from Rotterdam to Bremen. The ship, however, was seized, not by the British but by the French, and taken into Brest on March I, I915. While the shipowner was still negotiating for the release of his ship, which was ultimately condemned and confiscated by a French prize court under a French interpretation of the Declaration of London, the shipper immediately requested the French Government to adhere to the British assurance; and on obtaining assent, requested the French government and the Bureau of War Risk Insurance, insurers of the cargo, that the cargo be not forwarded to Rotterdam, but that it be purchased, as he had made all his arrangements accordingly. He received from the French Government the full Bremen contract price. He then began suit against the-shipowner for the return of the prepaid freight, on the ground that the ship had failed to deliver her cargo at Rotterdam, her original destination. Although he subsequently reduced his claim alternatively to a pro rata return, his claim was completely dismissed by the United States District Court and by the Circuit Court of Appeals $^{45}$ on the ground (I) that there was no equity in his claim; (2) that he had voluntarily substituted the port of Brest for Rotterdam as a destination; and (3) that by so doing, he had himself deprived the shipowner of the possibility of delivering the cargo at Rotterdam, as the latter had the privilege of doing by transshipment in another steamer if necessary.

(b) Where a substituted or alternative destination, measurably near the original one, was within the contemplation of the shipper or the contract, or has been accepted by the shipper to his pecuniary advantage, full freight has been allowed.

These cases are naturally uncommon; yet there have been several whose peculiar facts showed that the shipper was desirous of having the cargo at the substituted port, though this was not mentioned in the contract. The allowance of full freight could not therefore be made under the contract, but was made either under the equitable jurisdiction of a court of admiralty or under a new implied contract. The cases arose first in prize courts, which admittedly have a wide jurisdiction

${ }^{4}$ Owens v. Breitung, supra note 10. 
as to allowance of freight, but the equitableness of the rule of maritime law adopted has induced its acceptance in other courts.

Lord Stowell first dealt with this type of case in the Prize Court. The case of The Diana ${ }^{48}$ involved a shipment made by British merchants on a Dutch vessel from a Dutch colony to Amsterdam, Holland, sent there because of the narrow colonial policy of the early nineteenth century evidenced here by the regulations of Holland, but intended really to be reshipped to London, the natural market of the goods. War having broken out, the ship was seized and the cargo restored to its British owners, and the question was whether full freight should be allowed the captors, who stood in the shoes of the shipowner. Lord Stowell, then Sir William Scott, held that London having been the real intended destination in the contemplation of the shippers, though not the chartered destination, and the substituted destination being exceedingly beneficial to them, full freight should be allowed. He admitted that mere accidental advantage accruing from a fortuitous entry into an intermediate port would not vary the ordinary rule that freight is conditioned on delivery at destination, but in this case he concluded that the substituted destination was the real one within the contemplation of the shipper.

Lord Stowell in his opinion in The Friends $s^{47}$ explained on equitable considerations his allowance of full freight to certain American ships bound for Holland and France, which were taken into England under the prohibitory Orders in Council, the cargo being released and sold advantageously in England. He said:

"In the case of the American ships bound to France or Holland, which were brought into the ports of this country under the prohibitory law, the full freight was pronounced to be due where the owners of the cargoes elected to sell here; where they did not elect to sell here, the court left it to them to settle the freight with the owners of the ships. The court considered a voyage from America to this country very nearly the same in effect as a voyage to those contiguous countries to which those vessels were originally destined; in all probability the markets of this country were not less favorable than in the blockaded ports, and no doubt. the sale was effected with every attention to the interests of the owners of the cargo. In those cases the court gave the master the full benefit of the freight, not by virtue of his contract, because looking at the charter-party in the same point of view as the courts of common law, it could not say that the delivery at a port in England, was a specific performance of its terms. But there being no contract which applied to the existing state of facts, the court found itself under an obligation to discover what was the relative equity between the parties. This court sits no more than the courts of common law do to make contracts between parties; but as a court exercising an equitable jurisdiction, it considers itself bound to provide, as well as it can, for that relation of interests which has unexpectedly

* (1803, Adm.) 5 C. Rob. 68. No such preference of the shippers appeared in The Fortuna, supra note 30 , so that the ordinary rule of no freight was applied.

- (1810, Adm.) Edw. 246. 
taken place under a state of facts out of the contemplation of the contracting parties in the course of the transaction."

Sir Robert Phillimore, in his decision in The Teutonia, ${ }^{48}$ stated that though these decisions were made in prize jurisdiction, they were authoritative, as Lord Tenterden had said, in the Admiralty Court generally. In that case, it will be recalled the Privy Council allowed full freight ${ }^{49}$ for a delivery at Dover instead of Dunkirk, France, an illegal destination for the German ship by reason of the outbreak of the Franco-Prussian War, on the ground that the charter-party permitted of a construction making Dover an alternative destination.

The case of Owens v. Breitung, recently decided by the Circuit Court of Appeals, allowed full freight to the shipowner on the ground that the shipper had elected the intermediate port as his alternative destination. ${ }^{.0}$

In these cases the cargo-owner is deemed to have accepted delivery at a place different from that originally agreed upon, but under circumstances indicating that such delivery was intended to be treated as a substituted or substantial performance of the contract.

(c) Prize courts prior to 1856 frequently decreed full freight to neutral ships seized because of their enemy cargoes, even where the cargoes were ultimately restored to the shippers.

Prior to the Declaration of Paris, when the neutral flag did not necessarily cover enemy cargo, it was the practice to seize the neutral ship, unload the noxious cargo and then permit the ship to proceed. It was customary to pay the vessel full freight, however small a part of the voyage may have been completed, capture being treated as equivalent to delivery. The captors had, of course, prevented the completion of the voyage and it was unfair that the neutral should be thus penalized, in the absence of culpability, especially when the captor could without hardship afford to be generous out of his unexpected spoils. ${ }^{51}$

This rule has been applied in prize courts even where the suspected cargo was ultimately released..$^{52}$ While the ship was deemed obliged to wait a reasonable time to see what happened to the cargo, Lord Stowell favored the shipowner by requiring but a short stay. Even where the ship was still in port after a long detention, he did not require

- (I87I, Adm.) L. R. 3 A. \& E. 394, 421.

- (1872, P. C.) I. R. 4 A. C. 171, 183. See also the prize cases of The Juno, supra note 20, at p. 175, dictum of Sir Samuel Evans, and The Iolo, note 21, at p. 216, in which latter case practically full freight was allowed.

"Supra note 10: "The sum and substance of the matter is that the libellant agreed to substitute the port of Brest for the port of Rotterdam." (Per curiam.)

"The Copenhagen (1799, Adm.) I C. Rob. 289; The Prosper (1809, Adm.) Edw. 72, 76. (The Danish neutral ship having by the outbreak of war with Denmark become an enemy, her full freight was then seized by the British Crown in prize.)

* The Racehorse, supra note Ia. 
her to reload the restored cargo as a condition of her right to claim full freight; ${ }^{53}$ he decided in The Hoffnung that the unlivery of the cargo had terminated the contract of affreightment. But if that were so, then he ought not to have required the ship to wait even a reasonable time, as he said in The Racehorse, to see what befell the cargo. Of course, if the ship, though neutral, was guilty of carrying simulated papers or contraband, no freight would be allowed her on captured or detained goods. ${ }^{54}$

At the beginning of the recent war, several British ships happened to be on voyages with German goods destined for Germany. The voyage, of course, became illegal by the outbreak of war. In The Juno, ${ }^{55}$ a British ship thus freighted put into an English port, but instead of full freight being allowed as in the case of capture, Sir Samuel Evans decreed only freight pro rata, submitting the amount to reference. It is not clear why the old principle of the neutral ship with enemy cargo should not have been applied to the supervening illegality of a voyage to the enemy, ${ }^{56}$ except on the theory that the British ship may be deemed affected with a disability not attributable to a neutral; on this theory no freight would have been allowed, but for the fact that she had sailed before the outbreak of war.

In the cases where full freight has been decreed notwithstanding an uncompleted voyage it will have become apparent that the fault or cause lay with the cargo or its owner.

\section{PRO RATA FREIGHT}

The determination of a rule of law as to pro rata freight is made difficult by the fact that courts both of common law and of admiralty or prize have dealt with the subject; the former, seeking to find a guide and justification in the strict principles of contract law, the latter seeking to do equity or justice between ship and cargo. It is well, therefore, in endeavoring to establish a rule to deal with each separately, and to direct attention to the operative facts which may be deemed to have influenced the court's decision in particular cases.

The question of pro rata freight has arisen where an unexpected contingency, such as peril of the sea or capture, has placed the owners of the cargo in control of their goods at a place short of the original destination. It has already been observed that when the goods are taken by the owner against his will, either from the master or at the hands of the court, in specie or in' the form of the proceeds of a sale, no freight is due. On the other hand, if he demands the goods, but the master desires and is able to go on within a reasonable time, the

ss The Marthe (1800, Adm.) 3 C. Rob. 106, note; The Hoffnung (1805, Adm.) 6 C. Rob. 232.

The Rising Sun (1799, Adm.) 2 C. Rob. 104; The Sarah Christina (1799, Adm.) I C. Rob. 237.

Supra note 20 .

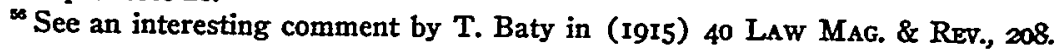


shipper can have them only on paying full freight. What then of the case where both shipper and master are willing to have the goods taken over by the shipper at an intermediate port and to dispense with the further carriage? Here the courts, in seeking to justify some allowance of freight, have spelled out of the circumstances a tacit renunciation of the original contract and a new implied agreement on the part of each to pay and accept, respectively, freight pro rata itineris peracti. The rule in its customary form is well stated by Baron Parke in Vlierboom v. Chapman.57

"To justify a claim for pro rata freight there must be a voluntary acceptance of the goods at an intermediate port, in such a mode as to raise a fair inference that the further carriage of the goods was intentionally dispensed with."

The difficulty arises in determining under the circumstances what is a "voluntary acceptance." The acts of both master and shipper ought to require equal scrutiny, for both must consent in order that a new agreement may be inferred. In the usual case of shipwreck and salvage or of capture of ship and cargo, shipowner and cargoowner each looks after his own interest without collaboration, and the courts must then determine from the conduct of each what was his intention with respect to the contract of affreightment. It seems, however, that the actions of the shipper are of greater interest to the courts, the presumption being that the master, if his ship is repaired or released, or if he is given an opportunity to hire another ship, would wish to go on with the carriage. Hence the master is often passive in the matter. He need not offer to send the goods forward. ${ }^{58}$ He need merely show that he was in a position to go on within a reasonable time, provided the shipper does not relieve him even of

${ }^{87}$ Supra note 29. Among the best of the American cases illustrating the principle of pro rata freight, and exemplifying various forms of "voluntary acceptance" are: Pinto v. Atwater (1804, Conn.) I Day, 193; Williams v. Smith (1804, N. Y. Sup. Ct.) 2 Caines, 13 ; Coffin v. Storer (1809) 5 Mass. 252; Gray v. Waln (1816, Pa.) 2 S. \& R. 229, 257; Propeller Mohazk (1868, U. S.) 8 Wall. I53; British and Foreign Marine Ins. Co. v. Southern Pacific Co. (1896, C. C. A. 2d) 72 Fed. 285 .

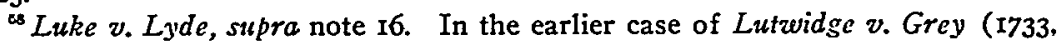
H. L.) in Abbott, Shipping (5th ed., I827) 307, it even seems that the master of a ship from Virginia to Glasgow, disabled off Ireland, refused to send the goods on to Glasgow, their destination, but only to "Great Britain," yet pro rata freight was allowed; probably this would not be followed to-day. The shippers themselves forwarded the goods to Glasgow, and doubtless the benefit they received from the carriage to Ireland influenced the decision. In Luke v. Lyde the facts would also seem to show that the master was requested to carry the goods from Biddleford to Lisbon, but declined, and yet pro rata ireight was allowed. The conditions upon which pro rata freight is now allowed which in addition to voluntary acceptance by the shipper, practically always involve some benefit to him from their carriage to the intermediate port, are negatived by the facts in Luke $v$. Lyde. Even where the British Vice-Consul, acting under instructions from the shipper, forwarded the goods from an intermediate port to their destination, where they were accepted by the shipper, pro rata freight to the intermediate port 
this burden by demanding the goods at once. It is the conduct of the shipper to which the courts will look in determining whether the acceptance was voluntary. If he insists on having his goods at once, without giving the master an opportunity to carry them on or to indicate his intentions, he will be held to pay full freight. But if he accepts them under circumstances showing that he is neither too eager to take them out of the hands of the master nor so reluctant as to indicate distinct opposition, ${ }^{50}$ his acceptance will be deemed to have been voluntary, provided the master was in a position to go forward with the cargo then or shortly thereafter and did not oppose their surrender.

A somewhat different situation arises where the goods are sold at the intermediate port by a court of admiralty, in salvage, prize or other proceedings. It has been observed that when the master sold the goods, whether justifiably or not, without the consent of the owners, no freight was allowed, even where the shipper accepted the proceeds. ${ }^{.0}$ The absence of any option to have the goods go forward deprived the acceptance of the proceeds of its voluntary character.

The question arises, where the sale is made by the court on its own authority in the interests of all parties, whether freight pro rata ought not to be allowed. Although the question has been much debated and decided in different ways, the weight of authority denies the right of the shipowner to freight, if the sale was effected without consent of the shipper.

In The Friends, ${ }^{01}$ a ship had gone up to the very mouth of the river of her port of destination, when she was captured. After recapture, both ship and cargo were sold to pay salvage, and Lord Stowell allowed the shipowner, "as a court exercising an equitable jurisdiction," half the charter freight. Justice Story disapproved this decision in The Nathaniel Hooper, asserting that Lord Stowell himself had practically overruled the decision in his later judgment in The Louisa. ${ }^{62}$ In The Nathaniel Hooper, Story refused to allow pro rata freight on various lots of cargo sold by the court to pay duties or salvage or by reason of its perishable nature.

There is, however, a dictum by Lord Mansfield in Baillie v. Moudig-

was allowed the shipowner on the ground that the acceptance by the Vice-Consul under instruction was a constructive acceptance there by the shippers themselves. Mitchell v. Darthez (1836, C. P.) 2 Bing. N. C. 555, 570. In The Leptir, supra note 35 , pro rata freight was allowed in a salvage suit at an intermediate port, where the cargo-owners requested delivery. It would seem, on principle, that full freight might well have been allowed; but it is not clear that the ship was in a position to go on.

${ }^{5}$ In The Nathaniel Hooper, supra note Io, the master first offered to carry the goods on in the ship when repaired, but afterwards sold the ship, making their carriage impossible; the owners therefore took the goods with what Judge Story called "a reluctant acquiescence forced upon them by an overruling necessity." He allowed pro rata freight, a decision which to-day would be more than doubtful, although it would be the general rule in continental maritime law.

${ }^{\infty}$ Supra, p. 374. $\quad$ Supra note $47 . \quad$ Supra note 15. 
liani $i^{63}$ that when ship and cargo were sold in prize proceedings under a condemnation subsequently reversed, that the shipowner ought to have pro rata freight out of the proceeds of the sale of the cargo, neither ship nor cargo being in fault; and this dictum receives much support from Lord Ellenborough's opinion in Hunter v. Prinsep, ${ }^{64}$ for had ship and cargo been released in specie, the vessel would have had the privilege of going on to earn her full freight. So where in a sale of the cargo for salvage at an intermediate port the owners were requested to put up a bond to secure the release of the cargo, but declined, it was concluded that they had assented by implication to take the money in place of the goods and were therefore liable for pro rata freight. ${ }^{\text {es }}$

From prize cases no definite principles can be derived. ${ }^{66}$ In a case where both cargo and ship were restored, first the former and some time afterwards the latter, Lord Stowell allowed pro rata freight to the ship on the ground that by act of the court an innocent shipowner had been prevented from completing his contract. ${ }^{67}$ When the cargo was in fault, but not the ship, we have seen that captors were usually allowed full freight. Yet during the recent war when voyages to Germany became illegal to British ships which put into England and discharged their enemy cargoes, Sir Samuel Evans allowed only pro rata freight, laying down the following rule for the guidance of referees: ${ }^{\text {B }}$

"Such a sum is to be allowed for freight as is fair and reasonable in all the circumstances, regard being had to the rate of freight originally agreed (although this is not necessarily conclusive in all cases), to the extent to which the voyage has been made, to the labour and cost expended, or any special charges incurred in respect of the cargo seized before its seizure and unlivery, and to the benefit accruing to the cargo from the carriage on the voyage up to the seizure and unlivery; but no sum is to be allowed in respect of any inconveniences or delay attributable to the state of war or to the consequent detention and seizure."

Doubtless this rule interprets correctly the modern standards and criteria for the allowance of pro rata freight in cases of uncompleted voyages.

This study will have shown the danger of accepting without qualification the general formula that "freight is not earned unless the cargo is delivered."

\footnotetext{
"Supra note 28 . Supra note 27. "The Soblomsten, supra note 44.

- Justice Hough in The Appam, supra note 16, at p. 234, pointed out that in prize cases all incidental matters, including freight, are adjusted in the prize court. He added: "But whether full or pro rata freight is allowed, the award is ex aequo et bono, and not by virtue of any contract . . . ."

"The Copenhagen, supra note $5 \mathrm{r}$.

* The Juno, supra note 20 , at p. 175. But if British ship and cargo be regarded as equally in fault or under disability, then the pro rata rule may appear generous. See The Friends, supra note 47. The German Code (Arts. 631, 634) gives certain rules as to calculation of pro rata freight.
} 